\section{Cirurgia redutora de volume pulmonar}

Gostei do artigo sobre cirurgia redutora (Cirurgia redutora de volume pulmonar: critérios de seleção de pacientes no Hospital Universitário Antônio Pedro, Universidade Federal Fluminense, Niterói, Rio de Janeiro, RJ - Rev Assoc Med Bras 2003; 49(3): 274-7) e minha impressão é que se trata de um trabalho de "garimpo" conseguir pacientes aptos à cirurgia, já que a maioria deles apresentam comorbidades como mostrado no artigo. Porém, gostaria de tirar algumas dúvidas:

I. Pelo que entendi, não foi realizada pletismografia nos pacientes que participaram no estudo. O próprio artigo cita que é importante avaliação dos volumes, principalmente o volume residual.

2. Os pacientes não foram submetidos a exame de difusão de CO. Esse exame não traria subsídios para melhor indicação da CRVP?

3. Ergoespirometria: todos os pacientes foram submetidos a teste de caminhada, que sem dúvida, permite uma avaliação razoável. Mas, em se tratando do tipo de pacientes em avaliação, não seria mais conveniente contar com um exame mais detalhado como a ergoespirametria? Creio que se poderia tirar muito mais subsídios desse exame. Gostaria de saber a opinião dos autores.

Nivaldo luiz Botega

OURINHOS - SP

\section{Resposta dos autores}

Sem dúvida, são levantadas questões importantes em relação ao artigo por nós publicado sobre cirurgia redutora de volume pulmonar, sendo necessários alguns esclarecimentos.

Em relação à pletismografia e estudo da difusão, esta foi realizada no paciente que foi submetido ao procedimento cirúrgico. Reservamos estes exames para os pacientes que após serem aprovados para cirurgia aceitem serem submetidos ao procedimento. Tal paciente apresentava volume residual de $173 \%$ do previsto no pré-operatório e pudemos constatar redução para 120\% do previsto no pós-operatório.

Em relação à avaliação funcional, encontramos meIhora sensível ao compararmos o pré-operatório CVF de 2,0I litros, VEFI de 0,79 litros sem resposta ao teste broncodilatador com o pós-operatório no qual encontramos CVF de 2,4I litros, VEFI de I,03I também sem resposta aos broncodilatadores.

No estudo da difusão pulmonar pudemos observar melhora entre o pré-operatório DNA de I,61 ou 39\% do previsto no pré-operatório e DNA de 3,45 ou $72 \%$ do previsto no pós-operatório.

Embora concorde que a ergoespirometria nos daria dados não obtidos ao teste de caminhada por seis minutos (TC6M), optamos pelo (TC6M), por ser um exame simples e facilmente reprodutível, não necessitando equipamentos dispendiosos para os diversos serviços que desejem realizar avaliação de pacientes com DPOC. No paciente selecionado e operado, pudemos constatar melhora entre o pré e pós-operatório, com o paciente caminhando $290 \mathrm{~m}$, efetuando duas paradas devido à dispnéia intensa e referindo um índice de dispnéia de Borg de 5 no pré-operatório e após a cirurgia caminhando $390 \mathrm{~m}$ sem interrupções e referindo um índice de dispnéia de Borg igual a I.

Rodolfo fred Behrsin

Niteról - RJ

\section{"Cólica ureteral e estresse emocional"}

Recentemente tomei conhecimento de artigo publicado no International Journal of Epidemiology em 1997 (vol 26, no 5) denominado "Stressful Life Events and Risk of Symptomatic Kidney Stones" de autoria conjunta de cinco professores da New Jersey Medical School (Preventive Medicine and Community Healty Departament, Surgery/Urology Departament). Ocorre que publiquei em 1995, portanto dois anos antes, na RAMB - Revista da Associação Médica Brasileira [4I(2):
125-9] estudo denominado "Cólica ureteral e estresse emocional" (Ureteral colic and emotional stress), com o mesmo objetivo e praticamente a mesma metodologia, chegando às mesmas conclusões. Seria para mim muito honroso tal fato, haja visto a importância do tema e a publicação norte-americana ser considerada "Qualis A International" na área de epidemiologia, no entanto, o meu trabalho sequer foi citado nas referências bibliográficas daquele artigo publicado dois anos depois. Embora reconhecendo que não há uma obrigação legal de citação do artigo original, há por outro lado a obrigação ética, indiscutível de se respeitar a precedência e originalidade na área de pesquisa. Portanto, causa estranheza tal omissão, uma vez que a Revista da Associação Médica Brasileira é uma das publicações médicas mais respeitadas no Brasil, uma das poucas indexadas no Medline, a mesma base do International Journal of Epidemiology. Vale acrescentar que a minha pesquisa remonta há vários anos antes da publicação, visto a dificuldade de levá-la a cabo solitariamente e com exíguos recursos, situação que me obrigou a lançar mão de uma metodologia de baixo custo que é o desenho do tipo caso-controle. No entanto, tais limitações não me impediram de elaborar hipóteses na área da fisiopatologia dos eventos manifestos como cólica ureteral em pessoas predispostas, numa tentativa de apontar caminhos para a prevenção de tão grave problema de saúde pública. Ora, a possibilidade de predição de risco, para o evento cólica ureteral, certamente pode trazer melhoria da qualidade de vida para tais pacientes e enorme economia de recursos tão escassos em nosso país. Com o objetivo de dar um enfoque positivo ao problema aqui colocado, penso que trata-se de mais uma oportunidade de chamar a atenção dos colegas médicos brasileiros para tão importante problemática.

EnIDIO lLario

Professor do Núcleo de Biótica ética MúpIca da Faculdade de CiênCias Médicas da Universidade Estadual de Campinas e médico do Centro de Referência em Reabilitação de Campinas 